\title{
The Catabolism of Phenanthrene and Naphthalene by Bacteria
}

\author{
By H. KIYOHARA AND K. NAGAO \\ Department of Applied Chemistry, Okayama College of Science, \\ 1-1 Ridai-cho, Okayama 700, Japan
}

(Received 4 July 1977; revised 18 October 1977)

Thirteen strains of bacteria able to grow on phenanthrene were isolated from soil; they included fluorescent and non-fluorescent pseudomonads, vibrios and unidentified bacteria. Two of the pseudomonads, like Aeromonas sp. s45P1, also grew on naphthalene. In all strains, growth on phenanthrene induced the enzyme responsible for the conversion of 1-hydroxy-2-naphthoate to 2-carboxybenzaldehyde, NAD-dependent 2-carboxybenzaldehyde dehydrogenase and protocatechuate oxygenase, but not salicylate hydroxylase, catechol oxygenase or NAD(P)H-dependent 1-hydroxy-2-naphthoate hydroxylase. Growth on naphthalene induced salicylate hydroxylase and catechol oxygenase. It is suggested that the catabolism of phenanthrene occurs via protocatechuate in all these bacteria, and that the pathways for degradation of phenanthrene and naphthalene are separate.

\section{INTRODUCTION}

With the development of the petroleum industry, there has been an increase in the amount of polyaromatic hydrocarbons released into the environment. As part of a study of the mechanism of degradation of hydrocarbons by micro-organisms, we have examined the catabolism of phenanthrene by bacteria. The enzymic steps involved in the conversion of phenanthrene to 1-hydroxy-2-naphthoate by a soil pseudomonad were elucidated by Evans, Fernley \& Griffiths (1965). The naphthoate was then presumed to be oxidatively decarboxylated to 1,2-dihydroxynaphthalene which would be further degraded through the naphthalene-catabolizing pathway described by Davies \& Evans (1964). However, Aeromonas sp. s45p1, which was isolated from soil by Kiyohara, Nagao \& Nomi (1976), did not convert 1-hydroxy-2-naphthoate to 1,2-dihydroxynaphthalene but instead metabolized it to 2carboxybenzaldehyde which was then oxidized to $o$-phthalate, by an NAD-dependent dehydrogenase, and finally to protocatechuate (Fig. 1). The cleavage of the naphthoate (Kiyohara \& Nagao, 1977) involves the fission of the bond between the carbon atoms bearing the hydroxyl and carboxyl groups by an intradiol type of dioxygenase which acts in a similar way to gentisate oxidase (EC 1.13.1.4) (Sugiyama et al., 1958).

The work described in the present paper shows that the protocatechuate pathway is the only pathway for degradation of phenanthrene in 13 independent isolates of soil bacteria. The relationship between the pathways for degradation of phenanthrene and naphthalene is also described.

\section{METHODS}

Bacterial strains and media. Bacteria able to grow on phenanthrene were isolated from soil by enrichment culture in phenanthrene/salts medium, followed by plating on Pseudomonas $\mathrm{F}$ agar (Difco). The salts medium contained $\left(\%, w / v\right.$, in tap water): $\left(\mathrm{NH}_{4}\right)_{2} \mathrm{HPO}_{4}, 0 \cdot 5 ; \mathrm{KH}_{2} \mathrm{PO}_{4}, 0 \cdot 15 ; \mathrm{Na}_{2} \mathrm{HPO}_{4} .12 \mathrm{H}_{2} \mathrm{O}, 0.15 ;$ $\mathrm{MgSO}_{4} .7 \mathrm{H}_{2} \mathrm{O}, 0.02 ; \mathrm{NaCl}, 0.05$; the $\mathrm{pH}$ was 7.3 without adjustment. Phenanthrene $(0.3 \%, \mathrm{w} / \mathrm{v})$ was added to the medium before autoclaving at $120^{\circ} \mathrm{C}$ for $15 \mathrm{~min}$. The phenanthrene was melted by the heat but was finely dispersed by vigorously shaking the flasks after cooling. Naphthalene, which was crystallized from 


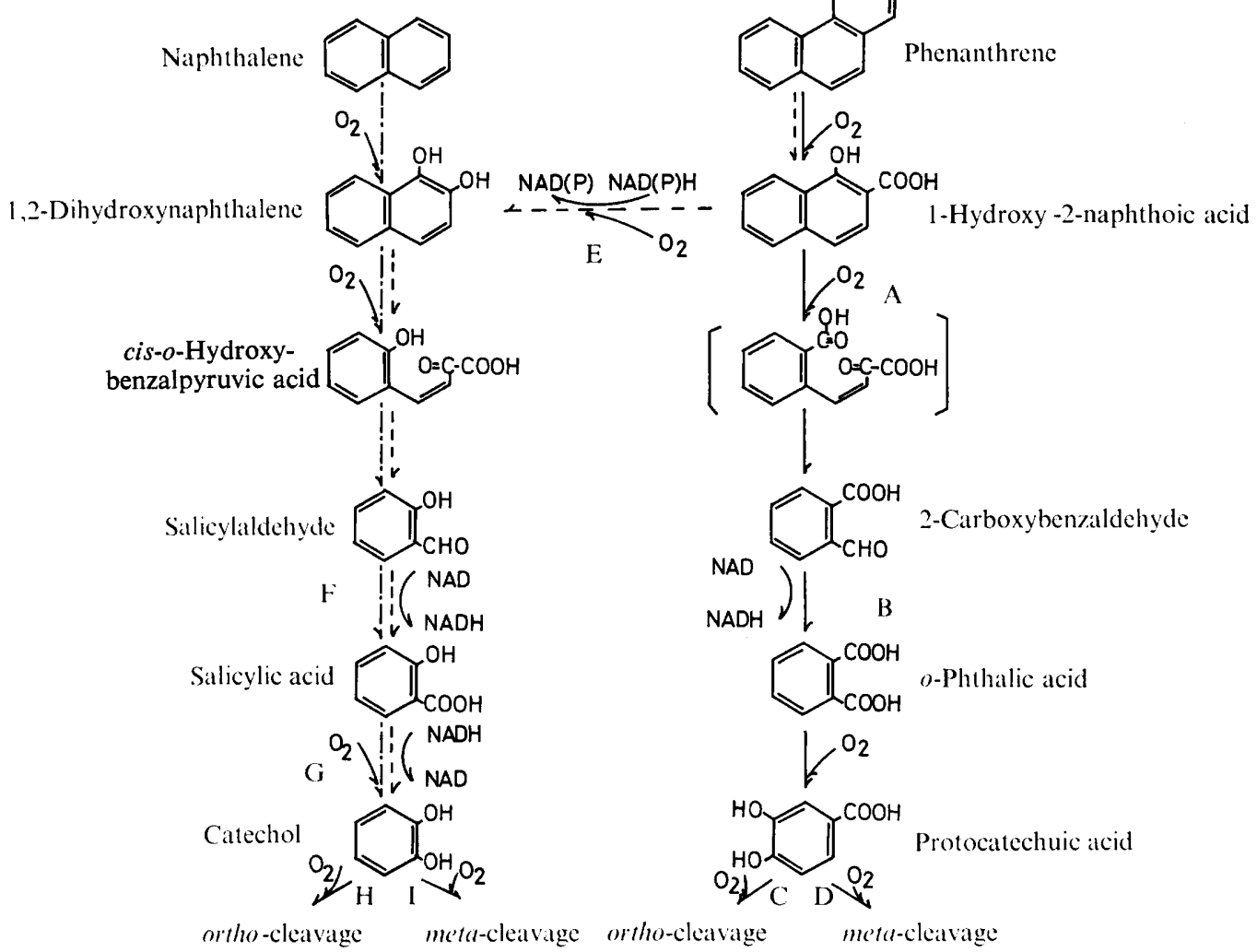

Fig. 1. Pathways proposed for the degradation of phenanthrene and naphthalene:---, Evans et al. (1965); -.-.-., Davies \& Evans (1964); - __._, Kiyohara et al. (1976).

Enzymes: A, 1-hydroxy-2-naphthoate-degrading enzyme; B, 2-carboxybenzaldehyde dehydrogenase; C, protocatechuate 3,4-oxygenase; D, protocatechuate 4,5-oxygenase; E, 1-hydroxy-2naphthoate hydroxylase; F, salicylaldehyde dehydrogenase; G, salicylate hydroxylase; $\mathrm{H}$, catechol 1,2-oxygenase; I, catechol 2,3-oxygenase.

acetone-water and aseptically collected by filtration, was added to salts medium after autoclaving. Heatlabile substrates were sterilized by membrane filtration (Sartorius, $0.2 \mu \mathrm{m}$ pore size); other substrates were autoclaved in the salts medium.

Diagnostic tests on the isolated strains were carried out according to Pelczar (1957), Hasegawa (1975), Holding \& Collee (1971), Gibbs \& Skinner (1966) and Stanier, Palleroni \& Doudoroff (1966). Identifications were according to Buchanan \& Gibbons (1974).

Preparation of extracts. Bacteria ( $2 \mathrm{ml}$ suspension), which had been subcultured in phenanthrene/salts medium (10 ml) in a large test tube for $2 \mathrm{~d}$ at $30^{\circ} \mathrm{C}$, were inoculated into salts medium (100 ml) containing $0.3 \%$ (w/v) carbon source in $500 \mathrm{ml}$ conical flasks and shaken (155 reciprocations $\left.\min ^{-1}\right)$ for 18 to $20 \mathrm{~h}$ at $30{ }^{\circ} \mathrm{C}$. The bacteria were centrifuged at $20000 \mathrm{~g}$ for $20 \mathrm{~min}$ at $5{ }^{\circ} \mathrm{C}$, washed twice with sterile $10 \mathrm{~mm}$ $\mathrm{NaH}_{2} \mathrm{PO}_{4} / \mathrm{K}_{2} \mathrm{HPO}_{4}$ buffer, $\mathrm{pH} 7 \cdot 1$, and suspended in the same buffer (approx. $8 \mathrm{mg}$ dry wt ml ${ }^{-1}$ ). This cell suspension was used for measurements of $\mathrm{O}_{2}$ uptake. To prepare extracts, the suspension was homogenized by sonication at $20 \mathrm{kHz}$ (type T-A-4201 sonic oscillator; Marine Instruments Co., Tokyo, Japan) for three periods of $5 \mathrm{~min}$ at $5{ }^{\circ} \mathrm{C}$ and centrifuged at $106000 \mathrm{~g}$ for $30 \mathrm{~min}$. The supernatant liquid was used as the extract for enzyme assays.

Enzyme assays. Published procedures were used for assay of the following enzymes: catechol 1,2-oxygenase [catechol: oxygen 1,2-oxidoreductase (decyclizing); EC 1.13.11.1] (Hegeman, 1966); catechol 2,3-oxygenase [catechol:oxygen 2,3-oxidoreductase (decyclizing); EC 1.13.11.2] (Feist \& Hegeman, 1969); protocatechuate 3,4-oxygenase [protocatechuate:oxygen 3,4-oxidoreductase (decyclizing); EC 1.13.11.3] (Fuj isawa $\&$ Hayaishi, 1968); protocatechuate 4,5-oxygenase [protocatechuate:oxygen 4,5-oxidoreductase (decyclizing); EC 1.13.11.8] (Ono, Nozaki \& Hayaishi, 1970); protocatechuate 2,3-oxygenase (Crawford, 1975); salicylaldehyde dehydrogenase (Shamsuzzaman \& Barnsley, 1974); salicylate hydroxylase [salicylate, 
NADH:oxygen oxidoreductase (1-hydroxylating, decarboxylating); EC 1.14.13.1] (Yamamoto et al., 1965); and 1-hydroxy-2-naphthoate-degrading enzyme (Kiyohara \& Nagao, 1977). Catechol 1,2-oxygenase and salicylate hydroxylase could not be assayed directly in extracts with a high activity of catechol 2,3oxygenase and in these cases the 2,3-oxygenase was inactivated by treating the extracts with $30 \mathrm{mM}-\mathrm{H}_{2} \mathrm{O}_{2}$ for $1 \mathrm{~min}$ at $30^{\circ} \mathrm{C}$. Protocatechuate 3,4-oxygenase was assayed after inactivation of the 4,5-oxygenase in the same manner.

1-Hydroxy-2-naphthoate hydroxylase was assayed by following the formation of NADH or NADPH under the same conditions as were used for salicylate hydroxylase except that 1-hydroxy-2-naphthoate was used as substrate.

2-Carboxybenzaldehyde dehydrogenase was measured spectrophotometrically by following the formation of NADH at $30^{\circ} \mathrm{C}$ in a $1 \mathrm{~cm}$ light-path cuvette. The reaction mixture $(3.0 \mathrm{ml})$ contained: $0.5 \mathrm{ml}$ extract; $0.5 \mathrm{ml} 1.2 \mathrm{~mm}-\mathrm{NAD} ; 1.5 \mathrm{ml} 48.3 \mathrm{~mm}-\mathrm{Na}_{2} \mathrm{HPO}_{4}(\mathrm{pH} 8.0) ; 0.5 \mathrm{ml} 2.4 \mathrm{~mm}$-2-carboxybenzaldehyde was added to initiate the reaction.

Protein was estimated by the method of Lowry et al. (1951) using crystalline bovine albumin as a standard.

Oxygen uptake by intact bacteria. The capacity of intact bacteria to oxidize substrates was measured by conventional manometric techniques. Each Warburg vessel contained $10 \mathrm{mmol}$ substrate and chloramphenicol (final concn $100 \mu \mathrm{g} \mathrm{ml}^{-1}$ ) in $2.0 \mathrm{ml} \mathrm{NaH} \mathrm{PO}_{4} / \mathrm{K}_{2} \mathrm{HPO}_{4}$ buffer, $\mathrm{pH} 7 \cdot 1$, in the main compartment; $1 \mathrm{ml}$ cell suspension (approx. $8 \mathrm{mg}$ dry wt) in the side-arm; and $0.2 \mathrm{ml} 20 \%(\mathrm{w} / \mathrm{v}) \mathrm{KOH}$ in the centre well. Rates of $\mathrm{O}_{2}$ uptake are expressed as $\mu \mathrm{l} \mathrm{O}_{2}$ consumed h$^{-1}(\mathrm{mg} \text { dry wt })^{-1}$.

Chemicals. All chemicals used were obtained commercially: phenanthrene ( $99 \%$ purity), 1-hydroxy-2naphthoic acid (extra pure), protocatechuic acid (extra pure), catechol (guaranteed grade), disodium $o$-phthalate (guaranteed grade), benzoic acid (guaranteed grade) and disodium succinate (extra pure) from Tokyo Chemical Industry Co., Tokyo, Japan; naphthalene (guaranteed grade) and sodium salicylate (guaranteed grade) from Ishizu Pharmaceutical Co., Osaka, Japan; crystalline bovine albumin from Seikagaku Kogyo Co., Tokyo, Japan; NAD ( $98 \%$ purity), NADH ( $98 \%$ purity), NADPH ( 98 to $99 \%$ purity) and FAD ( 94 to $99 \%$ purity) from Sigma.

\section{RESULTS AND DISCUSSION}

We isolated 13 strains of bacteria able to grow on phenanthrene. All were Gram-negative, motile, polar-flagellate rods. Six of these strains (s15P1, s47P1, s179P3, s179P21, s182P1 and s185P1) produced diffusible, fluorescent pigment on Pseudomonas F agar; tests for catalase, oxidase, reduction of nitrate and denitrification were positive; Voges-Proskauer and $\mathrm{H}_{2} \mathrm{~S}$ formation tests were negative; no growth was observed at $41^{\circ} \mathrm{C}$. These strains were therefore termed 'fluorescent pseudomonads'. Three strains (s175P1, s184P1 and s187P1) differed only in their failure to produce pigment; they were termed 'non-fluorescent pseudomonads'. Two strains (s176P1 and s183P1) were termed 'vibrios' because they formed luminescent colonies and attacked glucose oxidatively and fermentively without the evolution of gas. s183P1 produced indole and $\mathrm{H}_{2} \mathrm{~S}$ and gave a positive Voges-Proskauer test. The other two isolates could not be assigned to any group. In addition, strain s7 5 was isolated from soil by using kerosene as sole source of carbon and energy and was a non-fluorescent pseudomonad.

All strains able to grow on phenanthrene also grew on $o$-phthalate and $p$-hydroxybenzoate (Table 1). Only Aeromonas sp. s45P1 and the fluorescent pseudomonads s15P1 and s47P1 grew on naphthalene as well as on phenanthrene. All strains gave a yellowish orange colour in phenanthrene/salts media after about $15 \mathrm{~h}$ growth. The phenotype of the ability to assimilate naphthalene was represented as $\mathrm{Nah}^{+}$by Dunn \& Gunsalus (1973) and we have expressed the ability to assimilate phenanthrene as $\mathrm{Phn}^{+}$. According to this designation, s45P1, s47P1 and s15P1 were $\mathrm{Phn}^{+} \mathrm{Nah}^{+}, \mathrm{s} 7 \mathrm{~K} 5$ was $\mathrm{Phn}^{-} \mathrm{Nah}^{+}$, and the other strains were $\mathrm{Phn}^{+} \mathrm{Nah}^{-}$. These characteristics were unstable. S47P1 lost the $\mathrm{Nah}^{+}$character to become $\mathrm{Phn}^{+} \mathrm{Nah}^{-}$and both s45P1 and s15P1 gave rise to $\mathrm{Phn}^{-} \mathrm{Nah}^{+}$and $\mathrm{Phn}^{+} \mathrm{Nah}^{-}$phenotypes in the course of this work. Both characters were liable to disappear during prolonged storage on nutrient agar slants or during transfer to different growth substrates. In particular, $\mathrm{Nah}^{+}$ was completely lost by growing on benzoate but $\mathrm{Phn}^{+}$and the ability to grow on salicylate were not lost under these conditions. It is possible that $\mathrm{Nah}^{-}$isolates might have lost their $\mathrm{Nah}^{+}$character during enrichment with phenanthrene. 
Table 1. Growth of strains on aromatic compounds as sole sources of carbon

Organisms were inoculated into basal medium $(10 \mathrm{ml})$ containing different carbon compounds $(0.3 \%, w / v)$ and shaken at $30^{\circ} \mathrm{C}$ for $7 \mathrm{~d}$.

Growth on:

\begin{tabular}{|c|c|c|c|c|c|c|c|}
\hline \multirow[b]{2}{*}{ Group } & \multirow[b]{2}{*}{ Strain } & \\
\hline & & $\begin{array}{l}\text { Phenan- } \\
\text { threne }\end{array}$ & $\begin{array}{c}o- \\
\text { Phthalate }\end{array}$ & $\begin{array}{c}p \text {-Hydroxy } \\
\text { benzoate }\end{array}$ & $\begin{array}{l}\text { Naphtha- } \\
\text { lene }\end{array}$ & Salicylate & Benzoate \\
\hline Aeromonas sp. & $\mathrm{s} 45 \mathrm{P} 1$ & + & + & + & + & + & + \\
\hline \multirow{3}{*}{$\begin{array}{l}\text { Fluorescent } \\
\text { Pseudomonas sp. }\end{array}$} & $\mathrm{s} 15 \mathrm{P} 1, \mathrm{~s} 47 \mathrm{P} 1$ & + & + & + & + & + & + \\
\hline & s179P3, s182P1 & + & + & + & - & + & + \\
\hline & s179p21, s185P 1 & + & + & + & - & - & - \\
\hline \multirow{3}{*}{$\begin{array}{l}\text { Non-fluorescent } \\
\text { Pseudomonas sp. }\end{array}$} & s $7 \mathrm{~K} 5$ & - & - & - & + & + & - \\
\hline & $\mathrm{s} 175 \mathrm{P} 1$ & + & + & + & - & + & + \\
\hline & $\mathrm{s} 184 \mathrm{P} 1, \mathrm{~s} 187 \mathrm{P} 1$ & + & + & + & - & - & - \\
\hline \multirow{2}{*}{ Vibrio sp. } & $\mathrm{s} 176 \mathrm{P} 1$ & + & + & + & - & - & - \\
\hline & $\mathrm{s} 183 \mathrm{P} 1$ & + & + & + & - & + & + \\
\hline Unidentified & $\mathrm{s} 172 \mathrm{P} 12, \mathrm{~s} 190 \mathrm{P} 2$ & + & + & + & - & - & - \\
\hline
\end{tabular}

Table 2. Oxidation of possible metabolic intermediates of phenanthrene and naphthalene by bacteria which had been grown on phenanthrene

Bacteria (approx. $8 \mathrm{mg}$ dry wt) which had been grown on phenanthrene $(0 \cdot 3 \%, \mathrm{w} / \mathrm{v})$ for 18 to $20 \mathrm{~h}$ were tested manometrically for their ability to oxidize substrates $(10 \mathrm{mmol})$ in the presence of chloramphenicol $\left(100 \mu \mathrm{g} \mathrm{ml}^{-1}\right)$. Phenanthrene and naphthalene were used as fine powders. Measurements were corrected for endogenous respiration [approx. $0.9 \mu 1 \mathrm{O}_{2} \mathrm{~h}^{-1}(\mathrm{mg} \text { dry wt })^{-1}$ ].

Rates of oxidation $\left[\mu 1 \mathrm{O}_{2}\right.$ uptake $\mathrm{h}^{-1}\left(\mathrm{mg}\right.$ dry wt) $\left.{ }^{-1}\right]$ of:

\begin{tabular}{|c|c|c|c|c|c|c|c|c|c|}
\hline Strain & $\begin{array}{c}\text { Phenan- } \\
\text { threne }\end{array}$ & $\begin{array}{c}1- \\
\text { Hydroxy- } \\
2- \\
\text { naph- } \\
\text { thoate }\end{array}$ & $\begin{array}{c}\text { 2- } \\
\text { Carboxy- } \\
\text { benzalde- } \\
\text { hyde }\end{array}$ & Phthalate & $\begin{array}{l}\text { Protocate } \\
\text { chuate }\end{array}$ & $\begin{array}{l}\text { Naphtha- } \\
\text { lene }\end{array}$ & $\begin{array}{l}\text { Salicyl- } \\
\text { aldehyde }\end{array}$ & Salicylate & Catechol \\
\hline $\mathrm{s} 45 \mathrm{P} 1$ & $27 \cdot 0$ & $20 \cdot 7$ & $14 \cdot 4$ & $20 \cdot 0$ & $26 \cdot 6$ & 0.8 & 1.8 & $1 \cdot 0$ & $2 \cdot 2$ \\
\hline s15P1 & $19 \cdot 3$ & $41 \cdot 3$ & NT & $17 \cdot 7$ & $12 \cdot 2$ & $4 \cdot 3$ & NT & $2 \cdot 0$ & $5 \cdot 3$ \\
\hline $\mathrm{s} 47 \mathrm{P} 1$ & $16 \cdot 6$ & $24 \cdot 9$ & NT & $12 \cdot 8$ & $7 \cdot 6$ & 6.8 & NT & $3 \cdot 0$ & 1.4 \\
\hline s179P3 & $33 \cdot 6$ & $35 \cdot 1$ & $35 \cdot 7$ & $7 \cdot 7$ & $26 \cdot 1$ & 11.9 & $5 \cdot 2$ & 6.5 & $4 \cdot 5$ \\
\hline s179P21 & $21 \cdot 6$ & 42.9 & $32 \cdot 9$ & $16 \cdot 9$ & $36 \cdot 6$ & 23.9 & 1.0 & $6 \cdot 1$ & $6 \cdot 4$ \\
\hline s182P1 & $32 \cdot 6$ & $37 \cdot 4$ & $60 \cdot 7$ & $20 \cdot 6$ & $29 \cdot 0$ & $34 \cdot 2$ & $4 \cdot 6$ & $4 \cdot 0$ & $5 \cdot 7$ \\
\hline $\mathrm{s} 185 \mathrm{P} 1$ & $37 \cdot 8$ & $28 \cdot 1$ & $30 \cdot 9$ & $15 \cdot 6$ & 31.0 & $4 \cdot 5$ & $4 \cdot 3$ & - & $2 \cdot 4$ \\
\hline$s 175 P 1$ & $34 \cdot 4$ & $36 \cdot 4$ & $38 \cdot 0$ & 18.9 & $54 \cdot 7$ & $5 \cdot 0$ & $10 \cdot 5$ & $1 \cdot 8$ & $8 \cdot 2$ \\
\hline $\mathrm{s} 184 \mathrm{P} 1$ & $27 \cdot 8$ & $48 \cdot 6$ & $25 \cdot 8$ & $17 \cdot 4$ & $20 \cdot 0$ & $4 \cdot 0$ & 9.9 & 0.9 & 5.9 \\
\hline $\mathrm{s} 187 \mathrm{P} 1$ & $40 \cdot 1$ & $37 \cdot 7$ & $32 \cdot 2$ & $12 \cdot 3$ & $13 \cdot 4$ & $32 \cdot 7$ & $10 \cdot 2$ & $7 \cdot 8$ & $5 \cdot 5$ \\
\hline $\mathrm{s} 176 \mathrm{P} 1$ & $34 \cdot 4$ & $26 \cdot 3$ & 57.0 & $25 \cdot 1$ & 45.8 & $8 \cdot 2$ & $9 \cdot 4$ & 0.7 & $5 \cdot 4$ \\
\hline s183P1 & $25 \cdot 7$ & $45 \cdot 0$ & $57 \cdot 1$ & $22 \cdot 0$ & $52 \cdot 9$ & $40 \cdot 1$ & 8.6 & $4 \cdot 5$ & 7.0 \\
\hline $\mathrm{s} 172 \mathrm{P} 12$ & $32 \cdot 4$ & $36 \cdot 4$ & $34 \cdot 4$ & $5 \cdot 4$ & $33 \cdot 4$ & 1.8 & - & 1.5 & - \\
\hline $\mathrm{s} 190 \mathrm{P} 2$ & $33 \cdot 5$ & $37 \cdot 3$ & $8 \cdot 1$ & $10 \cdot 1$ & 11.5 & $19 \cdot 7$ & 0.5 & 0.8 & - \\
\hline
\end{tabular}

-, No significant net $\mathrm{O}_{2}$ uptake; NT, not tested.

All $\mathrm{Phn}^{+}$strains which had been grown on phenanthrene oxidized 1-hydroxy-2-naphthoate, 2-carboxybenzaldehyde, $o$-phthalate and protocatechuate but showed little $\mathrm{O}_{2}$ uptake with salicylaldehyde, salicylate and catechol (Table 2). These results suggest that in all these strains, phenanthrene is catabolized through 1-hydroxy-2-naphthoate, 2-carboxybenzaldehyde, $o$-phthalate and protocatechuate, as has previously been shown for Aeromonas sp. S45P1 (Kiyohara et al., 1976). Five Nah- strains (s179P21, s182P1, s187p1, s183P1 and s190P2) oxidized naphthalene as well as phenanthrene. The supernatants after oxidation of naphthalene by these strains gave a yellow colour in alkali $\left(\lambda_{\max }=420 \mathrm{~nm}\right)$, which is similar to that of cis-o-hydroxybenzalpyruvate (Davies \& Evans, 1964). This suggests that 


\section{Table 3. Oxidation of possible metabolic intermediates of phenanthrene and naphthalene by $\mathrm{Nah}^{+}$strains which had been grown on naphthalene}

Bacteria (approx. $8 \mathrm{mg}$ dry wt) which had been grown on naphthalene $(0 \cdot 3 \%, \mathrm{w} / \mathrm{v})$ for 18 to $20 \mathrm{~h}$ were tested manometrically for their ability to oxidize substrates $(10 \mathrm{mmol})$ in the presence of chloramphenicol $\left(100 \mu \mathrm{g} \mathrm{ml}^{-1}\right)$. Phenanthrene and naphthalene were used as fine powders. Measurements were corrected for endogenous respiration [approx. $2 \cdot 0 \mu \mathrm{l} \mathrm{O}_{2} \mathrm{~h}^{-1}(\mathrm{mg} \text { dry wt) })^{-1}$ ].

Rates of oxidation $\left[\mu 1 \mathrm{O}_{2}\right.$ uptake $\mathrm{h}^{-1}\left(\mathrm{mg}\right.$ dry wt) ${ }^{-1}$ ] of:

\begin{tabular}{|c|c|c|c|c|c|c|c|}
\hline Strain & $\begin{array}{l}\text { Phenan- } \\
\text { threne }\end{array}$ & $\begin{array}{l}\text { 1-Hydroxy- } \\
\text { 2-naphthoate }\end{array}$ & $o$-Phthalate & $\begin{array}{c}\text { Protocate- } \\
\text { chuate }\end{array}$ & $\begin{array}{l}\text { Naphtha- } \\
\text { lene }\end{array}$ & Salicylate & Catechol \\
\hline $\mathrm{s} 45 \mathrm{P} 1$ & $1 \cdot 2$ & $1 \cdot 8$ & NT & $1 \cdot 2$ & $32 \cdot 1$ & $24 \cdot 5$ & $17 \cdot 9$ \\
\hline $\mathrm{s} 15 \mathrm{P} 1$ & $1 \cdot 4$ & 0.9 & 0.7 & $3 \cdot \overline{5}$ & $35 \cdot 5$ & $14 \cdot 0$ & $4 \cdot 2$ \\
\hline s7k5 & $6 \cdot 1$ & - & - & - & $67 \cdot 5$ & $56 \cdot 8$ & $57 \cdot 2$ \\
\hline
\end{tabular}

-, No significant net $\mathrm{O}_{2}$ uptake; NT, not tested.

the enzymes oxidizing phenanthrene in these strains also oxidize naphthalene. On the other

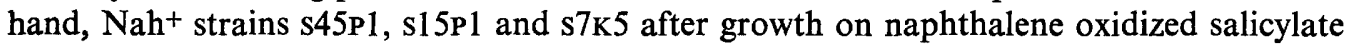
and catechol but not phenanthrene, 1-hydroxy-2-naphthoate, $o$-phthalate or protocatechuate (Table 3), suggesting that these strains catabolized naphthalene through catechol as proposed by Davies \& Evans (1964).

The measurements of $\mathrm{O}_{2}$ uptake by intact bacteria were confirmed by the results of enzyme assays (Table 4). All $\mathrm{Phn}^{+}$strains grown on phenanthrene contained 1-hydroxy-2naphthoate-degrading enzyme, 2-carboxybenzaldehyde dehydrogenase and protocatechuate oxygenase, but no significant activities of salicylate hydroxylase, catechol oxygenase or 1-hydroxy-2-naphthoate hydroxylase. The salicylaldehyde dehydrogenase activity may have been due to cross-specificity of 2-carboxybenzaldehyde dehydrogenase. 1-Hydroxy-2naphthoate-degrading enzyme and 2-carboxybenzaldehyde dehydrogenase were not present in bacteria grown on succinate.

$\mathrm{Nah}^{+}$strains which had been grown on naphthalene had salicylate hydroxylase and catechol oxygenase activities (Table 5). There was no detectable activity of 1-hydroxy-2naphthoate-degrading enzyme, 2-carboxybenzaldehyde dehydrogenase or protocatechuate oxygenase. Strain $\mathrm{s} 7 \mathrm{~K} 5$, the only strain isolated as $\mathrm{Phn}^{-}$, had especially high activities of salicylate hydroxylase and catechol 2,3-oxygenase, and even showed small but detectable activities of these enzymes after growth on succinate. These results confirm the suggestion that these strains metabolize naphthalene through the pathway proposed by Davies \& Evans (1964).

Protocatechuate and catechol are cleaved in three ways: by meta-cleavage, ortho-cleavage or both. Aeromonas sp. S45P1 metabolized protocatechuate and catechol by both the metaand ortho-cleavage pathways but Pseudomonas sp. s15P1 used only the ortho-cleavage pathway. $\mathrm{Phn}^{+}$strains (s179P21, s182P1, s185P1 etc.) oxidized protocatechuate by the metacleaving enzyme (Table 4). No $\mathrm{Phn}^{+}$strain had a protocatechuate 2,3-oxygenase similar to that found in Bacillus species by Crawford (1975).

None of the strains we isolated oxidized phenanthrene through salicylate and catechol or produced an $\mathrm{NAD}(\mathrm{P}) \mathrm{H}$-dependent 1-hydroxy-2-naphthoate hydroxylase, which would catalyse the decarboxylation of the naphthoate. In $\mathrm{Phn}^{+} \mathrm{Nah}^{+}$strains, the pathways for degradation of phenanthrene and naphthalene seem to be independent of each other, and not connected in the metabolic process of aromatic ring-fission. We conclude that the mechanism for catabolism of phenanthrene, which we proposed for Aeromonas sp. s45P1, occurs widely in bacteria.

We wish to thank Professor Dr R. Nomi of Hiroshima University for useful suggestions and Mr T. Hosaki for his help. 


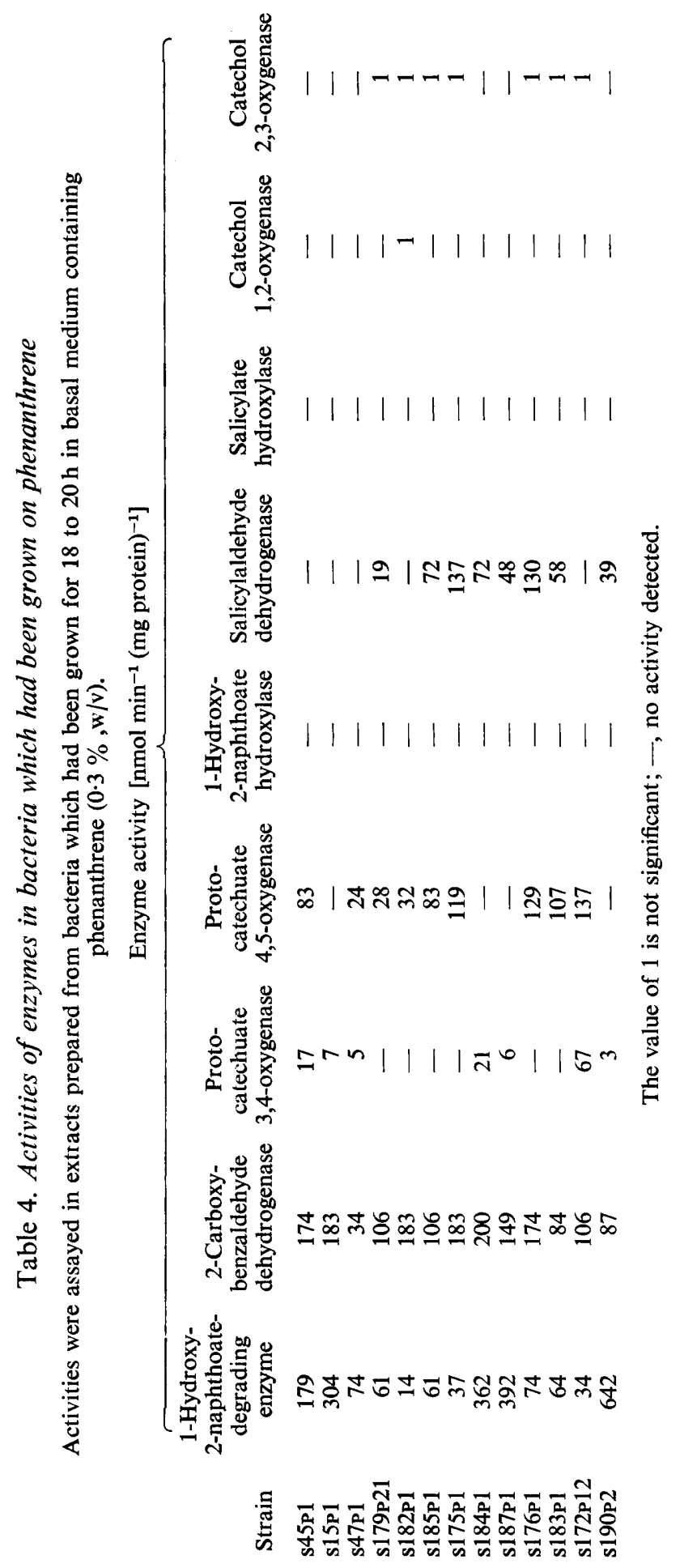


Table 5. Activities of enzymes of the pathway for naphthalene degradation in extracts of $\mathrm{Nah}^{+}$strains which had been grown on naphthalene or on succinate

Activities were assayed in extracts prepared from bacteria which had been grown for 18 to $20 \mathrm{~h}$ in basal medium containing naphthalene $(0 \cdot 3 \%, \mathrm{w} / \mathrm{v})$ or succinate $(10 \mathrm{~mm})$.

\begin{tabular}{|c|c|c|c|c|}
\hline \multirow[b]{2}{*}{ Strain } & \multirow[b]{2}{*}{$\begin{array}{l}\text { Growth } \\
\text { substrate }\end{array}$} & \multicolumn{3}{|c|}{$\begin{array}{c}\text { Enzyme activity } \\
{\left[\mathrm{nmol} \mathrm{min}^{-1}(\mathrm{mg} \text { protein })^{-1}\right]}\end{array}$} \\
\hline & & $\begin{array}{c}\text { Salicylate } \\
\text { hydroxylase }\end{array}$ & $\begin{array}{l}\text { Catechol } \\
\text { 1,2-oxygenase }\end{array}$ & $\begin{array}{l}\text { Catechol } \\
\text { 2,3-oxygenase }\end{array}$ \\
\hline \multirow[t]{2}{*}{$\mathrm{s} 45 \mathrm{P} 1$} & Naphthalene & 48 & 19 & 550 \\
\hline & Succinate & NT & - & - \\
\hline \multirow[t]{2}{*}{$\mathrm{s} 15 \mathrm{P} 1$} & Naphthalene & 61 & 4 & 1 \\
\hline & Succinate & NT & 一 & - \\
\hline \multirow[t]{2}{*}{$\mathrm{s} 7 \mathrm{k} 5$} & Naphthalene & 771 & - & 242 \\
\hline & Succinate & NT & - & 12 \\
\hline
\end{tabular}

The value of 1 is not significant; - , no activity detected; NT, not tested.

\section{REFERENCES}

BuchanaN, R. E. \& GibBons, N. E. (editors) (1974). Bergey's Manual of Determinative Bacteriology, 8th edn. Baltimore: Williams \& Wilkins.

CRAWFORD, R. L. (1975). Novel pathway for degradation of protocatechuic acid in Bacillus species. Journal of Bacteriology 121, 531-536.

Davies, J. I. \& Evans, W. C. (1964). Oxidative metabolism of naphthalene by soil pseudomonads. The ring fission mechanism. Biochemical Journal 91, 251-261.

DunN, N. W. \& Gunsalus, I. C. (1973). Transmissible plasmid coding early enzymes of naphthalene oxidation in Pseudomonas putida. Journal of Bacteriology 114, 974-976.

Evans, W. C., Fernley, H. N. \& Griffiths, E. (1965). Oxidative metabolism of phenanthrene and anthracene by soil pseudomonads. The ring fission mechanism. Biochemical Journal 95, 819-831.

Feist, C. F. \& Hegeman, G. D. (1969). Phenol and benzoate metabolism by Pseudomonas putida: regulation of tangential pathways. Journal of Bacteriology 100, 869-877.

Fujisawa, H. \& Hayaishi, O. (1968). Protocatechuate 3,4-dioxygenase. I. Crystallization and characterization. Journal of Biological Chemistry 243, 2673-2681.

GibBs, B. M. \& SkINNER, F. A. (1966). Identification Methods for Microbiologists, A. London \& New York: Academic Press.

Hasegawa, T. (1975). Classifications and Identifications of Microorganisms. Tokyo: Tokyo University Press.

Hegeman, G. D. (1966). Synthesis of the enzymes of the mandelate pathway by Pseudomonas putida. I. Synthesis of enzymes of the wild type. Journal of Bacteriology 91, 1140-1154.

Holding, A. J. \& Collee, J. G. (1971). Routine biochemical tests. Methods in Microbiology 6A, 1-32.
KIYOHARA, H. \& NAGAO, K. (1977). Enzymatic conversion of 1-hydroxy-2-naphthoate in phenanthrene-grown Aeromonas sp. S45P1. Agricultural and Biological Chemistry 41, 705-707.

Kiyohara, H., Nagao, K. \& Nomi, R. (1976). Degradation of phenanthrene through $o$-phthalate in an Aeromonas sp. Agricultural and Biological Chemistry 40, 1075-1082.

Lowry, O. H., Rosebrough, N. J., FARr, A. L. \& RANDALL, R. J. (1951). Protein measurement with the Folin phenol reagent. Journal of Biological Chemistry 193, 265-275.

Ono, K., Nosaki, M. \& Hayaishi, O. (1970). Purification and some properties of protocatechuate 4,5-dioxygenase. Biochimica et biophysica acta 220, 224-238.

Pelczar, M. J. (1957). Manual of Microbiological Methods. New York: McGraw-Hill.

Shamsuzzaman, K. \& Barnsley, E. A. (1974). The regulation of naphthalene metabolism in pseudomonads. Biochemical and Biophysical Research Communications 60, 582-589.

Stanier, R. Y., Palleroni, N. J. \& Doudoroff, M. (1966). The aerobic pseudomonads: a taxonomic study. Journal of General Microbiology 43, 159271.

Sugiyama, S., Yanao, K., Tanaka, H., Komagata, K. \& ARIMA, K. (1958). Metabolism of aromatic compounds by bacteria. I. Gentisic acid oxidase and protocatechuic acid oxidase of Pseudomonas ovalis S-5. Journal of General and Applied Microbiology 4, 223-240.

Yamamoto, S., Katagiri, M., Maeno, H. \& Hayaishi, O. (1965). Salicylate hydroxylase, a monooxygenase requiring flavin adenine dinucleotide. Journal of Biological Chemistry 240, 3408-3413. 